\title{
War and Violence in Sinan Antoon's The Corpse Washer
}

\author{
Radwa Ramadan Mahmoud \\ Department of English Language and Literature, Faculty of Women \\ Ain Shams University, 1, Asmaa Fahmi St. Heliopolis, Cairo, Egypt \\ E-mail: radwa.anan77@gmail.com
}

Received: 03-09-2015

Published: 01-03-2016
Accepted: 05-12-2015

doi:10.7575/aiac.ijalel.v.5n.2p.49
Advance Access Published: December 2015

URL: http://dx.doi.org/10.7575/aiac.ijalel.v.5n.2p.49

\begin{abstract}
War is the greatest source of violence in the world. It is the most disastrous expression of tendencies to violence innate to human nature. Iraq has suffered for a long time from the repercussions of war and violence and in this country ravaged by war trauma; the only space left for memory has been literature. Personal and political traumas have characterized the works of Iraqi writers who have been either victims of traumatic experience themselves or have been firsthand witnesses to trauma in Iraq. Literature provides them with an avenue to reclaim the humanity of all those who have been traumatized by the violence represented by war. Drawing on the theory of trauma, the paper seeks to explore the notions of war trauma and violence in Sinan Antoon's novel The Corpse Washer (2014) that reveals Iraq's traumatic and violent history. The paper examines the ways in which the novel bears witness to, protests against and exposes the devastating effects of war and violence.
\end{abstract}

Keywords: Iraq, narratives, Sinan Antoon, trauma, violence, war

\section{Introduction}

Iraq is a million broken mirrors scattered across a desert crushed by Rome's hooves. Blind barbarians must look for the pieces and wipe the blood off them without being devoured by the wolves, which howl and growl on both sides. Everything has changed now: The shoulder is a shelf for coffins. The eye a well of tears. The lung a valley for death. He must give the dead barbarians faces and names. And there are more every day. (Antoon, 2013, p. 33)

In the twentieth century, the world has become an ever more violent place; the growth of ethnic and sectarian conflicts and the rise of extremist movements have increasingly trapped people in unending chaos and violence. ${ }^{\mathrm{i}}$ Iraq has suffered from a long history of war and violence that has deeply affected generations of Iraqis. It has suffered from violent and recurrent change: the military coup of 1968 that put the Ba'th party and Saddam Hussein into power (19682003), the long and brutal war with Iran from 1980 to1988, the two Gulf wars of 1991 and 2003, a thirteen year economic embargo, and finally the post 2003 invasion and occupation era. ${ }^{\text {ii }}$

In Refractions of Violence, Martin Jay (2003) asserted that violence has become "a constitutive function of today's world, structuring and sustaining our way of existence and of socio-political and transnational intelligibility"(p.3). Michael Hardt and Antonio Nergi (2004) argued that contemporary warfare and violence have become "a permanent condition", "the primary organizing principle of society" and "the general matrix for all relations of power and techniques of domination" (p.12-13). In On Violence, political theorist Hannah Arendt (1970) stated that war is the most severe form of violence. Scarry (1985) defined war as "a form of human brutality where the main activity is injuring and the ultimate goal is to out-injure the opponent" (p.12).

Throughout the human civilizations, war and violence have been major themes in literature. War literature analyzes the effects of war on the human psyche, the different attitudes towards war and the interpretations of human nature and human violence. In Iraqi literature, the theme of war plays a prominent role. Writers repeatedly express their personal experiences with the horrors of war and delve deeply into how the repercussions of war and the unhealed war wounds have coloured their lives. They create narratives that cast war as destructive, perverse and traumatic.

Wars and sanctions have forced many writers out of Iraq and brought them into more contact with the cultural traditions of their host countries. Direct contact with western cultures has revitalized Iraqi literature. Iraqi writers in exile have been united in writing about a homeland that has suffered under repression, censorship, war, and occupation. Their writings deal with matters of identity, roots and belonging that would have been unimaginable if these writers did not live and write in the west (Mustafa, 2008, IV). Sinan Antoon, an Iraqi poet and novelist, who was born in Baghdad to an Iraqi father and an American mother, also moved away with his family to the United States after the 1991 Gulf War.

This paper seeks to investigate the notions of war trauma and violence through an analysis of Sinan Antoon's novel The Corpse Washer (2013), longlisted for the Independent Foreign Fiction Prize 2014 and winner of the 2014 Arab American Book Award given by the Arab American National Museum. ${ }^{\text {iii }}$ In The Corpse Washer, the trauma of recent 
Iraqi history is seen through the eyes of the protagonist, Jawad, an Iraqi young man born into a family that prepares bodies for burial.

For a theoretical framework, trauma theory has proved relevant and informative. Most of the works which formulate this theory were written in reaction to the Holocaust but they are, in most cases, applicable to other major historical traumas. A case in point is Cathy Caruth's books Trauma: Explorations in Memory (1995) and Unclaimed Experience: Trauma, Narrative and History (1996). Caruth is one of the most eminent figures in modern trauma studies, and her work has served as a basis for other researchers in the same field. Drawing on Caruth's books, the paper examines the interplay between war trauma, violence and narrative in Sinan Antoon's novel The Corpse Washer. It investigates the ways in which Antoon exposes the traumatic effects of war and violence.

\section{The Nature of Trauma}

The word "trauma" comes from the ancient Greek meaning "wound" (Marder, 2006). Originally the term has been used in medicine to denote "any injury where the skin is broken as a consequence of external violence and the effects of such an injury upon the organism as a whole" (Laplanche \& Pontalis, 1988, P. 465). Psychoanalysts adapt the term to represent an unrecoverable psychic shock caused by accidents. In The Language of Psychoanalysis, Laplanche and Pontalis (1988) interpret trauma as "an event in the subject's life defined by its intensity, by the subject's incapacity to respond adequately to it, and by the upheaval and long lasting effects that it brings about in the psychical organization" (P. 465). Laplanche and Pontalis (1988) characterize trauma as "a violent shock," "a wound," and "the consequences affecting the whole organization" (P. 466).

In its most primary origin, the Greek word "trauma" referred to an injury inflicted on the body rather than on the mind. In its later usage, it is used more and more to refer to conditions concerning the mind (Caruth, 1996, p. 3). Unlike the wounding of the body, which is a simple and in most cases healable injury, the wounding of the mind is much more complex because it is not experienced in real time, which makes it harder to register for our consciousness. For Caruth (1996), trauma is "a wound inflicted not upon the body but upon the mind". She uses the image of the wound to indicate that trauma can only be understood through literary or symbolical language (p. 3).

Freud has stated in Beyond the Pleasure Principle that "the wound of the mind - the breach in the mind's experience of time, self, and the world - is not, like the wound of the body, a simple and healable event" but rather an event that "is experienced too soon, too unexpectedly, to be fully known and is therefore not available to consciousness until it imposes itself again, repeatedly, in the nightmares and repetitive actions of the survivors" (cited in Caruth, 1996, 3-4). It is then one of the central paradoxes of trauma that although it originally derives from the Greek word meaning wound, it is not a simple wound that heals in the course of time as a physical injury does, but one that is not fully experienced at the time of its occurrence and instead manifests itself belatedly, often years after its originating event.

Caruth (1996) implies three essential characteristics of trauma, physical or external violence that intrudes into the psyche, belatedness or temporal gap between knowing and not-knowing and reverberation of the past traumatic event. Caruth states:

In its most general definition, trauma describes an overwhelming experience of sudden or catastrophic events in which the response to the event occurs in the often delayed, uncontrolled repetitive appearance of hallucinations and other intrusive phenomena. (p. 11)

The fact that the event was overwhelming for the victim means that "the victim's brain was not prepared for a shattering experience. The victim was not ready to feel pain and anxiety" (LaCapra, 2001, p. 90). Accordingly, the response to trauma is both delayed and intrusive; it interrupts the victims' ability to live in the present, returning in the form of dreams and flashbacks. Caruth (1995) remarks, "The event is not assimilated or experienced fully at the time, but only belatedly, in its repeated possession of the one who experiences it. To be traumatized is precisely to be possessed by an image or event" (p.4-5).

Hence, trauma has been used to indicate an overwhelming experience that fails to be integrated into the consciousness and continues to haunt its survivors later through flashbacks, dreams and intrusive thoughts. It has been characterized as an event or a series of events which "assume their force precisely in their temporal delay" (Caruth, 1995, p. 8), "a shock that creates a psychological split or rupture" (Felman, 2002, p. 171) and an experience that collapses the "distance between here and there, then and now" (LaCapra, 2001, p. 89). Similarly, Kai Erikson (1995) has stated that "trauma is generally taken to mean a blow to the tissues of the body - or more frequently now, to the tissues of the mind - that result in injury or some other disturbance" (p. 183). He has asserted that "something alien breaks in on you; smashing through whatever barriers your mind has set up as a line of defence" (p. 183).

\section{Trauma Literature: Speaking the Unspeakable}

According to Shoshana Felman (2002), "the twentieth century can be defined as a century of trauma," that was marked by tragic and violent events (p.171). Literature has become increasingly varied and abundant as writers try to depict feelings, thoughts and emotions that history either ignores or is unable to recover. Trauma literature involves delving into unknown wounds left by tragedy, speaking the unspeakable and remembering fragmented bodies. The goal of trauma literature, Vickory (2002) remarks, "is to help readers to access traumatic experience," particularly through the use of fictional trauma narrative (p. 1) By being "increasingly interested in the potential of trauma narratives to disclose 
silenced accounts of history", Contemporary literature "experiments with the ways in which trauma can be represented and attempts to deal with these experiences of human suffering" (Andermahr, 2013, p. 3).

Cathy Caruth (1966) emphasizes that literature is a nonpareil realm for representing traumatic experience. Literature, she argues, enables us "to bear witness to events that cannot be completely known and opens our ears to experiences that might have otherwise remained unspoken and unheard" (p. 2). Literature becomes a site for a belated enactment and witnessing of what can be referred to as the "unclaimed moment" of trauma (p. 3). Following Freud, Caruth argues that the language of trauma is inherently literary, "because literature, like psychoanalysis, is interested in the complex relation between knowing and not knowing" (p. 3). Caruth, further, suggests that this epistemological crisis in trauma functions as an interface between psychoanalysis and literary language: "it is at the specific point at which knowing and not knowing intersect that the language of literature and psychoanalytic theory of traumatic experience precisely meet" (p. 3).

\section{The Corpse Washer: A "Trauma Novel"}

A reading of Sinan Antoon's The Corpse Washer reveals that it can be labelled "a trauma novel". The term "trauma novel" refers to a work of fiction that conveys profound loss or intense fear on individual or collective levels (Balaev, 2008). The Corpse Washer is a "trauma novel" on two levels. First, in an individual sense, it is a narrative of the trauma its characters experience. Second on a broader historical level, it is the cultural product of a country with a traumatic history. In The Corpse Washer, Antoon redefines the trauma of war by exposing its violent psychological and emotional consequences. He explores the multiple faces of violence in Iraq. The violence in the street, made to the bodies of the victims, as well as the violence, less noticeable but even more shattering experienced by the minds and hearts of the Iraqis. He condemns the horrors of war, the targeted violence against civilians and the unmaking of the Iraqi character.

The Corpse Washer captures the experience of an Iraqi man who has lived through the war with Iran in the first half of the 1980s, the 1991 Gulf War, and then the 2003 occupation. Originally published in Arabic, The Corpse Washer tells the story of Jawad, a young man who is born to a family of corpse washers. His father was a respected man, who washed and shrouded the bodies of the dead before they were buried beneath the turbulent Iraqi soil. Jawad's life is set against the background of Saddam Hussein's regime. He decides to escape the family trade, choosing instead to become a sculptor. He enters Baghdad's Academy of Fine Arts in the late 1980s, against his father's wishes. Jawad chooses this alternative profession as an act of rebellion against death. Becoming a sculptor symbolises a desire to recreate bodies in reaction to accepting death in the available profession of burying. It is a resistance strategy whereby one defies temporality and extinction through art and recreation, a strategy reminiscent to that of Sinan Antoon himself who recreates a work of art, a novel to combat annihilation and amnesia.

The 2003 invasion and military occupation unleash sectarian violence. Life is torn apart by war and occupation. War turns the city into a graveyard, and the dead bodies are fished out of the rivers in masses, piling up across the city. Jawad asks himself: "who takes care of the dead, when death abandons the corpses to the living?" He, therefore, finds himself forced to continue his father's profession. Trained as an artist to shape materials to represent life, he now thinks how death shapes daily life and the bodies of Iraqi people. The traumatized experiences of Jawad's life, the loss and disappearance of his family members and friends and the haunting nightmares he recurrently has, make Jawad a very real character but leave him increasingly hopeless and alone. Antoon emphasizes Jawad's personal and national traumatic experiences that represent the growing fear, helplessness and the isolation that a traumatized person can experience during and after a traumatic event. He represents Kai Erikson's diagnoses of a traumatized individual who is completely invaded, and taken over by trauma. According to Erikson (1995), trauma becomes a dominating feature of the interior landscape of its victims- It "possesses" them and "threatens to drain [them] and leave [them] empty" (p. 183).

Antoon's novel displays Caruth's perspective of trauma as "wound." Noting Freud's view of trauma as "wound of the mind", Caruth (1996) insists that trauma involves a double wound, the wound of the original catastrophe and the wound of its recollection. Caruth then argues that "trauma seems to be much more than pathology, or the simple illness of a wounded psyche, it is always the story of a wound that cries out, that addresses us in the attempt to tell us of a reality or truth that is not otherwise available"( p. 4). Without trauma, in other words, the wound would be "unspoken or unrecognized." As Caruth (1996) carefully points out, however, "the originating wound is unspeakable, even unrecognizable, at the moment it is experienced. It is not available to consciousness until it imposes itself again repeatedly in the nightmares and repetitive actions of the survivors"(p. 4).

\section{Nightmares: A symptom of War Trauma}

Antoon depicts nightmarish episodes in the novel to underscore the indelible trauma suffered by Jawad. Nightmares have been prominent symptoms of war trauma. The dream imagery of the nightmare is used to understand the issues that arise from the traumatic experience. A recurring motif in the novel is Jawad's nightmares. As Kai Erikson (1995) remarks "trauma involves a continual reliving of some wounding experience in daydreams and nightmares, flashback and hallucinations and in a compulsive seeking out of similar circumstances" (p. 184). Jawad's nightmares are scattered throughout the novel. As if the violence during the day wasn't enough, Jawad is wracked by those devastating nightmares that are not presented as dreams but as reality, with lines such as "I start to suffocate, then bolt awake" (Antoon, 2014, p. 138).

Jawad's nightmares strikingly echo Caruth's theory of trauma. The novel opens with one such nightmare: Jawad watches as American soldiers carry off his beloved to rape her. "I try to run away, but they hold me tightly," Jawad 
narrates. "I scream again, but cannot hear my screams. I hear only Reem's shrieks, the laughter and grunts of the men, the sound of the rain" (Antoon, 2014, p. 2). The rape scene at the outset of the novel is important. Throughout history, invasion and occupation of countries are often described in terms of sexual violence. Nehru, when describing the British treatment of India writes, "They seized her body and possessed her, but it was a possession of violence. . . They didn't know her or try to know her. They never looked into her eyes, for theirs were averted and hers cast down through shame and humiliation" (Suleri, 1992). Likewise, Antoon uses rape in this scene as a metaphor for the suffering of Iraqi people. In a similar nightmarish dream, Jawad recounts:

I see Reem standing in an orchard full of blossoming pomegranate trees...I walk toward her and call out her name, but I can hear either my name nor the sound of my footsteps...All I hear is the wind rustling...I see two pomegranates on her chest instead of her breasts...I rush toward her, and when I reach her and hug her, the left pomegranate falls to the ground. When I bend down to pick it up, I see red stains bathing my arm. I turn back and see Reem crying as she tries to stop the fountain of blood gushing from the wound. (Antoon, 2014, p. 123)

The wound in Jawad's nightmare links body and mind. It does not only result from the seriousness of the wound but from Jawad's inability to hear his voice as well. Jawad's trauma includes personal loss and has larger historical dimensions too. By repeating his traumatic experiences, Jawad tries to negotiate with his traumatic past, to grasp its meaning and to assimilate it into his personal history. The compulsion to repeat reveals the traumatized subject's attempt to master his trauma.

His washing of the corpse of a man who looks exactly like his friend, triggers the memory of a forgotten wound for Jawad concerning the death of his dear friend Basim who died in his arms. They became close friends during his military service; Basim was "the star that lit the place for him" (Antoon, 2014, p. 56). In a flashback, Jawad remembers his friend. A flashback occurs when we are triggered to remember what has happened. It can be a terribly frightening experience involving all the senses. Jawad narrates:

American fighters jets hovered over our unit all the time...the no-fly zone was supposed to prevent the regime from oppressing citizens, but these fighter jets would kill innocent civilians and even herders. I never knew whether it was out of cheer idiocy or whether it was a game, using Iraqis for target practice ... we were awakened one day by the sound of massive explosion which shook the factory...Basim was one of six soldiers who died that day. (Antoon, 2014, p. 60)

Traumatic events, generally involving "threats to life or bodily integrity, or a close personal encounter with violence and death" (Herman, 1997, p. 33), intrude into the traumatized subject's everyday life and damage his world. Sayyid alFartusi, a friend of Jawad's father who had known him for years, had been in charge of collecting unclaimed, abandoned, and unidentified corpses from hospitals and from the morgue then they were washed, shrouded and properly buried. He faced many obstacles at first when he started the project but many do-gooders helped him with donations. Al-Fartusi wasn't a practicing or pious Muslim when he was young but what he saw during the withdrawal from Kuwait in 1991 transformed him completely. He recounts:

Musa's decision to abandon the highway saved our lives. Otherwise, we would've been charred like all the others I saw burning in their seats and whose remains were scattered all around us. The smell of the burning flesh and hair made me sick and tortured me in nightmares for months afterward. I could never forget the smell or the sight of stray dogs devouring soldier's bodies near Basra... Weeks after I returned, the nightmares started. I would see six or seven dogs tearing apart corpses...in another nightmare I would see my entire family being charred. (Antoon, 2014, p. 117-118)

The French poet and philosopher, Paul Valéry writes: "our memory repeats to us what we haven't understood" (cited in Felman, 2002, p. 231). In a similar vein, Kai Erikson (1995) remarks: “Our memory repeats to us what we haven't yet come to terms with, what still haunts us” (p. 184). Sayyid al-Fartusi's nightmares clearly echo Caruth's theory of trauma. He tells Jawad, "Whenever I think that humans have stooped to the lowest point, I discover that they can stoop even lower. The number of corpses thrown in garbage dumps and being fished out of the river has doubled in recent months." He continues; "even the dead are not safe anymore. They are booby-trapping corpses now" (Antoon, 2014, p. 116). He tells Jawad that "the roots of all this kept haunting me" and when Jawad asks him whether the dogs and nightmares have left him in peace, he answers "they left me alone, because they were afraid of what they saw in my other nightmares"( Antoon, 2014, p. 119). He becomes traumatized or in Caruth's words, he becomes "possessed by an image or event" (p. 5). Erickson (1995) states that the traumatized subject holds on to that moment, preventing it from slipping back into its proper chronological place in the past, "and relives it over and over again in the compulsive musings of the day and the seething dreams of night. The moment becomes a season, the events become a condition" (p. 184).

Most of the characters in the novel are traumatized by the experience of war, as Laurie Vickory (2002) remarks, "traumatic experience can produce a sometimes indelible effect on the human psyche that can change the nature of an individual's memory, self recognition and relational life" (p. 11). Traumatic events take away what the traumatized 
subject treasures most and leave him the indelible scar. The first part of the novel is written from memory, but in the second half Jawad's life turns into multiple narratives that are offered to Jawad as testimonies of the suffering of those who have left. They are full of anger emphasizing that exile is not always a place of safety, but of continuous struggle and pain. Iraq suffered from ongoing disasters. Sabri, Jawad's uncle, was a communist who fled away from Iraq for twenty five years because the regime was arresting communists. He used to follow the news about Iraq day by day on radio, newspapers, TV, and the internet. He never missed a piece of news. He visits Iraq after many years and he is shocked that the country has changed so much. His heart is broken, "Look at it now. Then you have all this garbage, dust, barbed wires and tanks ... this is not the Baghdad I'd imagined” (Antoon, 2014, p. 96). This scene recalls Scarry's definition of the effect of war as "alter[ing] the surface, shape, and deep eternity of the objects that human beings recognize as extensions of themselves" (p. 64). Jawad's uncle was against the war and demonstrated against it like millions all over the world. He said this was a process of erasure. Dictatorship and the embargo had destroyed the country. He says, "Now we had entered the stage of total destruction to erase Iraq once and for all" (Antoon, 2014, p. 85). Even the name of the state on his passport no longer existed. What happened to Iraq thus conforms to Scarry's designation of the target of war as erasure of 'civilization' in its most elemental form" (p. 61).

\section{The Unhealed Wounds of War}

War is a life or death situation. Death is the central metaphor in the novel. Jawad has to confront death every day. So death definitely conditions everything. The novel concentrates on corpses to reveal the Iraqi tragedy. Washing the dead is a difficult profession, but it puts us face to face with Iraq's trauma. "If death is a postman, then I receive his letters every day," remarks Jawad. "I am the one who opens carefully the bloody and torn envelopes. I am the one who washes them, who removes the stamps of death and dries and perfumes them" (Antoon, 2014, p. 3). For years, Jawad is haunted by the faces of the dead. He records the names of the dead and their causes of death in a notebook.

Freud divided the basic human drives into Eros and Thanatos, the two conceived as functioning in dynamic tension. He confirmed that the duality of human nature emerged from these two instincts. He considered Eros the instinct for life, love, and sexuality and in Thanatos the instinct of death and aggression. Influenced by Freud, Auden's great "September 1, 1939", a poem written on the first day of World War II, announces that "we must love one another or die." Similarly, Antoon in The Corpse Washer evokes devastation and death but also insists on an alternative to reassure his readers that there is still life among the wreckage of war. The relationship between Jawad and Reem provides welcome reprieve from the chaos that is powerfully overwhelming them. But then Reem suddenly disappeared; she developed breast cancer and left for Jordan. When doctors removed one of her breasts, Reem joined the line of Iraq's mangled bodies. Reem's cancer was a result of war, "the doctor back in Baghdad said that cancer rates have quadrupled in recent years and it might be the depleted uranium used in the ordnance in 1991," she writes in her last letter to Jawad (Antoon, 2014, p. 114). Reem's disappearance caused a "wound" and left a "scar" that had painfully affected Jawad. After that, he seemed unable to form the same attachment to anyone. "I knew that my heart was a hole one could pass through but never reside in," Jawad says (Antoon, 2014, p. 114).

After the death of Jawad's father, Hammoudy, his assistant, took over the washhouse. There were many corpses. "Most had been killed by the Americans... as well as those blown up by car bombs and other explosions" (Antoon, 2014, p. 104). But Hammoudy disappeared all of a sudden. Sayyid al-Fartusi tried to convince Jawad to take up his father's work. He urged him to open it and go back to work. He reminded him that the living had a debt and responsibility to the dead, "there are corpses scattered all over the streets and stuffed in fridges." The disappearance of both Hammoudy and Reem has affected Jawad deeply and has added to his trauma. Jawad withdrew into a kind of "protective envelope" in Erikson's words, "a place of mute, aching loneliness, in which the traumatic experience, is treated as a solitary burden that needs to be expunged by acts of denial and resistance" (p. 186).

For years, Jawad resisted his father's will. After his father's death, and due to his terrible need of money, Jawad finally gives in. His practice, although meticulous, is however not like his father's. War is a lived experience, an ongoing mess, and a destructive force and the corpses he is asked to wash are often nameless, or terribly disfigured. War shatters Jawad's world and changes his identity. As a corpse washer, Jawad has a unique understanding of the war in Baghdad. Like the pomegranate tree, Jawad stands alone, and lives on death.

The pomegranate tree is an important metaphor in the Corpse Washer that symbolizes the trauma of Iraq and reflects the suffering of Jawad. The water used in the washing of the corpses is not disposed of like other used waters. Through a small canal, the water is led to the garden tree outside Jawad's washhouse where it waters a thirsty pomegranate tree. Jawad couldn't eat the fruits of the pomegranate tree, "I am like the pomegranate tree, but all my branches have been cut, broken, and buried ... my heart [is] beating with death. But no one knows. No one. The pomegranate alone knows" (Antoon, 2014, p. 184). The pomegranate tree that stands in the courtyard of the washhouse, watered by the runoff from washing corpses, becomes a metaphor for Iraq.

Art is closely linked to immortality, a challenge to death and time, and a celebration of life. Another important symbol in the novel is the torture chair made by Jawad. After the invasion, Jawad participated in an exhibition of young and marginalized artists organized by the French Cultural Centre. He submitted a piece of art, a strange looking iron chair that he had found near the academy years ago. He bought some metal chains and added them to the chair's arms and front legs to look like an interrogation or torture chair. It is a very important symbol of the traumatic and violent nature of Iraq. Jawad tries to surmount his trauma by creating this piece of art. Jawad relates, "We'd thought the value of human life had reached rock bottom under the dictatorship and that it would now rebound, but the opposite happened. Corpses piled up like goals scored by death on behalf of rabid teams in a never-ending game" (Antoon, 2014, p. 108). 
Near the end of the novel, Jawad observes "History is what people call fate. And history is random and violent, storming and uprooting everything and everyone without ever turning back" (Antoon, 2014, p. 184). For Jawad, real history is random and violent, defying comprehension. History is trauma, and man is often at loss to cope with it.

\section{Conclusion}

In conclusion, The Corpse Washer is a "trauma novel" that conveys extreme loss and suffering both on individual and collective levels. Jawad, the protagonist, and most of the characters in the novel are traumatized by the experience of war. The novel bears witness to and protests against the shattering effects of war and violence. Antoon gives us a bleak portrait of Iraq as a battlefield and of the struggle of human spirit. He emerges as the chronicler of the Iraqi nightmare that has reduced Iraqis to corpses.

Antoon chooses the difficult profession of washing the dead to put us face to face with all of Iraq's traumas. As a corpse washer, Jawad has a unique understanding of the war in Baghdad. He tries to resist his trauma by choosing the sculpture profession as art is a challenge to death and a celebration of life. Jawad has hoped his statues would one day fill the city; instead it is corpses scattered all over the streets and stuffed in the fridges. Antoon is an adept witness to the severity of carnage produced by war; he describes the city and the repercussions of war with simple vivid details. He takes us through Jawad's life plagued by terrible nightmares brought on by violence that engulfs the city and the growing number of corpses that pass through the washhouse. What we are left with is not the shattering consequences of war and violence; but how trauma narrative describing these horrors of war is an act of resistance.

Finally, The Corpse Washer is the story of a wound that cries out, that tells and retells the Iraqi trauma that is not otherwise available. Iraqis are still victims of violence and witnesses of their country's destruction. Iraqis are still continuing to experience various forms of individual and collective traumas. While everyday life in Iraq is burdened with trauma and violence, Iraqis continue to resist and dream, trying to create art as ways of coping with despair and healing trauma and violence. Trauma not only destroys but creates. Writing about trauma is an act of creation, of binding together and of watering trees that stood as witnesses of life amidst destruction and bereavement.

\section{References}

Andermahr, S., \& Pellicer-Ortín, S. (2013). Trauma narratives and herstory. UK: Palgrave Macmillan.

Antoon, S. (2013). A Barbarian in Rome. In Al-Ali, Nadje \& Al-Najjar, Deborah. (Ed.) We are Iraqis: Aesthetics and politics in a time of war. New York: Syracuse University Press.

Antoon, S. (2014). The Corpse washer. London: Yale University Press.

Arendt, H. (1970). On violence. San Diego: Harcourt, Brace, Jovanovich.

Balaev, Michelle. (2008). Trends in literary trauma theory. Mosaic. 41 (2). Retrieved from https://www.questia.com/library/journal/1G1-235281138/trends-in-literary-trauma-theory

Bell, D. (2006). Memory, trauma and world politics: Reflections on the relationship between past and present. Basingstoke, England: Palgrave Macmillan.

Buelens, Gert, et al. (Eds.) (2014). The Future of trauma theory: Contemporary literary criticism. New York: Routledge, Taylor \& Francis Group.

Caruth, C. (1995). Trauma: Explorations in memory. Baltimore, MD: The Johns Hopkins University Press.

Caruth, C. (1996). Unclaimed experience: Trauma, narrative, and history. Baltimore, MD: The Johns Hopkins University Press.

Erikson, K. (1995). Notes on trauma and community. In Caruth, Cathy. Trauma: Explorations in memory (pp. 183199). Baltimore, MD: The Johns Hopkins University Press.

Felman, Sh. (2002). The Juridical unconscious: Trials and traumas in the twentieth century. Massachusetts: Harvard University Press.

Freud, S., \& Hubback, C J. M. (1990). Beyond the pleasure principle. London: International psycho-analytical Press.

Hardt, M., \& Negri, A. (2004). Multitude: War and democracy in the age of empire. New York: The Penguin Press.

Herman, J.L. (1997). Trauma and recovery. New York: Basic Books.

Hunt, N. C. (2010). Memory, war and trauma. Cambridge, Cambridge University Press.

Jay, M. (2003). Refractions of violence. New York: Routledge.

LaCapra, D. (2001). Writing history, writing trauma. Baltimore, MD and London: Johns Hopkins University Press.

Laplanche, J., Pontalis, J.B. (1988). The Language of Psychoanalysis. London: Karnac Books.

Marder, E. (2006). Trauma and literary studies: Some enabling questions. Reading on: Trauma, memory and testimony. 1 (1), 1-6. Retrieved from http://readingon.library.emory.edu/issue1/iss1 toc.htm

Mustafa, S. (2008). Contemporary Iraqi fiction: An anthology. Syracuse, N.Y: Syracuse University Press. 
Suleri, S. (1992). Rape as Metaphor. The Rhetoric of English India. Chicago: University of Chicago Press. Retrieved from http://www.postcolonialweb.org/poldiscourse/rape.html

Vickroy, L. (2002). Trauma and survival in contemporary fiction. Charlottesville: University of Virginia Press.

Whitehead, A. (2004). Trauma fiction. Edinburgh: Edinburgh University Press.

\section{Notes}

${ }^{\mathrm{i}}$ The 20th century was the most violent of human history. Over 100 million people were killed in two world wars. Many smaller wars claimed hundreds of thousands of lives. An estimated 170 million civilians were murdered by their own governments. Places like Afghanistan, Rwanda, Kuwait, Bosnia, Kosovo, Yugoslavia, along with others, experienced unimaginable violence and bloodshed. The 20th century made words like holocaust, genocide, terrorism, and mass suicide, very common and recurrent.

ii The Ba'th Party was the ruling party in Iraq from 1968 to 2003. The Ba'thists took power briefly in 1963 and regained it in 1968, after which the party's power became concentrated under Iraqi leader Saddam Hussein. The party was toppled in 2003 as a result of the Iraq War.

iiiSinan Antoon is a poet, novelist, translator and filmmaker. He was born in Baghdad in 1967 and moved to the USA after the 1991 Gulf War. He did his graduate studies at Georgetown and Harvard and has a $\mathrm{PhD}$ in Arabic literature from the latter. His poetry and articles (Arabic \& English) have appeared in various journals and publications. He has two collections of poems in Arabic which was published in English as The Baghdad Blues in April 2007 and One Night in All Cities in 2010. His first novel is I"jaam - an Iraqi Rhapsody. Translations of it have appeared in Italian, German, Portuguese and Norwegian. His second novel Wahdaha Shajarat al-Rumman (The Pomegranate Alone in 2010) was translated by himself and published as The Corpse Washer in 2013. This translation has won the 2014 Saif Ghobash Banipal Prize for Arabic Literary Translation, the 2014 Arab American Book Award of the Arab American National Museum (fiction category), and was longlisted for the 2014 Independent Foreign Fiction Prize. His third novel, $Y a$ Maryam was shortlisted for the 2013 International Prize for Arabic Fiction (The Arabic Booker). He returned to Iraq in 2003 to co-produce and co-direct the documentary film About Baghdad on the lives of Iraqis in a post-Saddam occupied Iraq. Sinan Antoon has taught Arabic literature at New York University since 2005 and is an associate professor at the Gallatin School, New York University. 